\title{
Isozyme inheritance in diploid Taraxacum hybrids
}

\author{
J. Hughes and \\ A. J. Richards
}

Department of Plant Biology, University of Newcastle upon Tyne, NE1 7RU, U.K.

Twelve enzyme systems were investigated by polyacrylamide gel electrophoresis in a population of diploid sexual Taraxacum hybrids. The genetic basis of isozyme bands was found by analysis of progeny phenotype segregation. Nine monomorphic and seven polymorphic loci were identified. Esterase isozymes could not be assigned to single Mendelian genes. The high level of heterozygosity found is related to the bréeding system of the population.

\section{INTRODUCTION}

The fundamental importance of breeding systems in determining genetic variation in plant populations, and the variety of reproductive strategies occurring in different plant species, have been emphasised by Lewontin (1974), Brown (1979) and Hamrick et al. (1979).

The genus Taraxacum is of particular interest in this context as it consists of closely related taxa with widely different breeding systems. There are about 2000 named species in the genus, 90 per cent of which are polyploids that reproduce asexually by obligate agamospermy. A small proportion of polyploids also produce some haploid ovules and are therefore facultative apomicts (Richards, 1970; Müller, 1972; Jenniskens, 1984). The majority of the 10 per cent diploid species which reproduce entirely sexually are obligate outcrossers; the remainder, a few relatively primitive species, are also capable of self-fertilisation.

Until recently it had been considered that diploid species in Europe occurred rarely and were confined to central and southern relict sites (Fürnkranz, 1960, 1961, 1966; Müller, 1972). It is becoming apparent however from the work of Dutch taraxacologists (den Nijs and Sterk, 1980, 1984a, b; Sterk et al., 1982; Jenniskens, 1984) that sexual species are widespread in their distribution throughout France, Germany, Switzerland and as far north as the Netherlands. It has also been shown that sexual and agamospermous reproduction can co-exist within the same "agamospecies". Not only does this have profound implications for the microsystematics of the genus, it also indicates that there may well be a flow of genetic information between agamospermous and sexual individuals.

In addition, there is a growing body of evidence that variation is generated by apomicts at a rate greater than that of background mutation. Genetic variation and adaptation have been shown to occur in parthenogenetic animals and apomictic plants (Asker, 1979). Mogie (1982) has demonstrated that individuals within obligately agamospermous Taraxacum species are not genetically identical and that the morphological and biochemical variation may be adaptive. Mogie and Richards (1983) suggest on karyological evidence that all 22 agamospecies in one section of Taraxacum (Hamata) have arisen asexually.

As a preliminary to a comparative study of the genetic variation associated with the four breeding systems of Taraxacum, an investigation was made into the inheritance of isozymes in material from a diploid population. As formal genetic analysis is not possible with apomictic plants, it is hoped that the establishment of the genetic basis of isozyme loci in diploid sexual species will enable analagous loci in polyploid apomicts to be identified.

\section{MATERIALS AND METHODS}

Electrophoretic studies were based on leaf-extracts from 28 greenhouse-grown plants established from seed collected in 1980 from 11 individuals at Serre Vebret, Auvergne, France. The plants were 
Table 1 Isozyme loci and variability in parental population

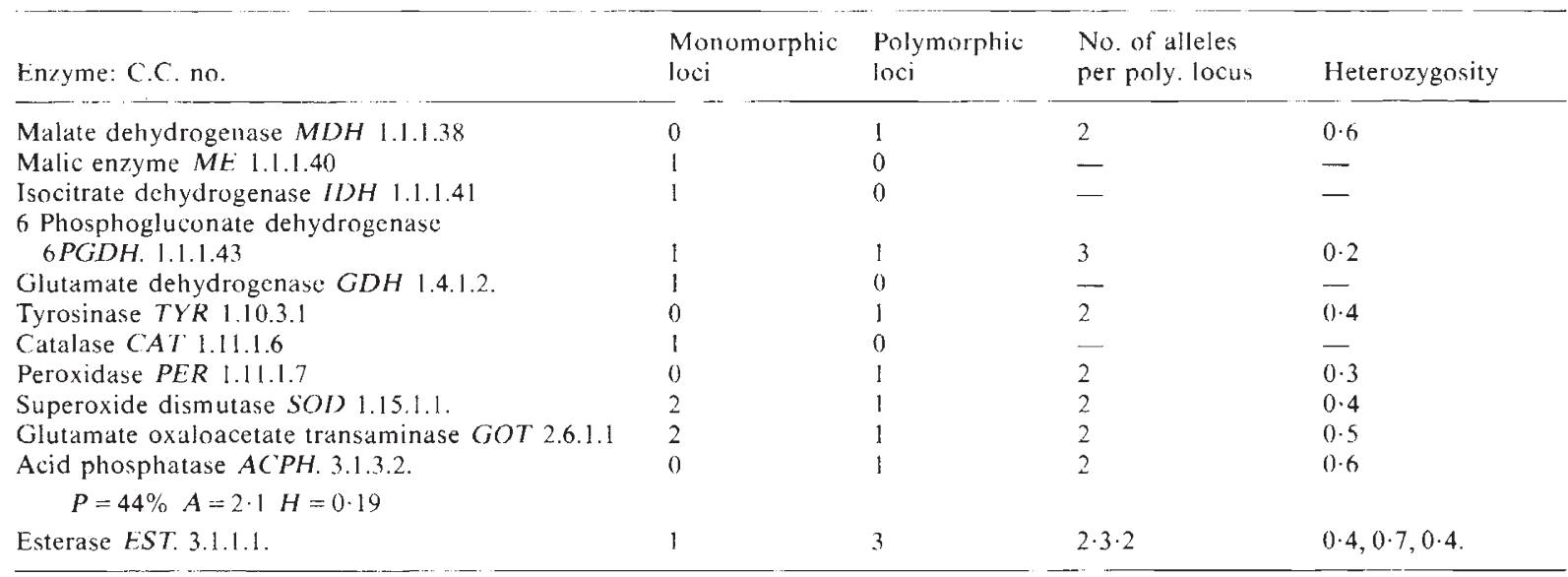

$P$ : percentage of polymorphic loci.

$A$ : mean number of alleles per polymorphic locus.

$H$ : mean heterozygosity per individual.

identified by AJR as Taraxacum alacre v. Soest, $T$. brevifloroides $v$. Soest and hybrids between these two species, and were found to be diploid (Mogie 1982) and self-incompatible (no seed was set in insect-free conditions in the absence of crossing). Crosses were made between individuals selected on the basis of observed esterase patterns, by rubbing together fully opened capitula, and 70 offspring were grown to maturity for genetic analysis. The enzymes listed in table 1 were investigated on polyacrylamide gels with discontinuous nondissociating buffer systems, using enzyme specific stains to visualise the resulting zymograms (Scan-

Table 2 Observed isozyme phenotypes

\begin{tabular}{|c|c|c|}
\hline Locus & Zymograms & $R_{1}$ \\
\hline$M D H$ & $-\cdots \equiv$ & $0.37,0.39,0.41$ \\
\hline$M E$ & - & $0 \cdot 28$ \\
\hline$I D H$ & $\equiv$ & $0 \cdot 29,0 \cdot 31,0 \cdot 33,0 \cdot 34$ \\
\hline $6 P G D H-1$ & $-\ldots$ & $0 \cdot 60$ \\
\hline $6 P G D H-2$ & $\equiv$ & $\begin{array}{l}0.40,() \cdot 42,0 \cdot 44,0 \cdot 46, \\
0.48\end{array}$ \\
\hline$G D H$ & - & $0 \cdot 18$ \\
\hline$T Y R$ & $-\cdots \cdot+\cdots=$ & $0 \cdot 26,0 \cdot 24$ \\
\hline$C A T$ & - & $0 \cdot 96$ \\
\hline$P E R$ & $\cdots-=$ & $0 \cdot 87,0 \cdot 89$ \\
\hline$S(O D)-1$ & $-=$ & $0.85,0.88$ \\
\hline$S O I)-2$ & $-\cdots-$ & 0.75 \\
\hline$S O D-3$ & - & $0 \cdot 58$ \\
\hline GOT-1 & $-\cdots-\cdots$ & $0.51,0.53$ \\
\hline$G O T-2$ & $\equiv$ & $(0.40,0.42,0.44$ \\
\hline$G O T-3$ & $\equiv=$ & $0.33,0.35,0.36$ \\
\hline$A C P H$ & $-\cdots-=$ & $0.92,0.94$ \\
\hline$E S T-1$ & $-\cdots$ & 0.75 \\
\hline$E S T-2$ & -...- - & $0.66,0.67$ \\
\hline EST-3 & - & 0.58 \\
\hline$E S T-4$ & $-\cdots$ & $0 \cdot 36$ \\
\hline
\end{tabular}

dalios 1969). Denaturation of the enzymes by protease activity associated with the abundant latex of dandelions was minimised by the addition of finely-ground Dowex $\mathrm{Cl}$, ascorbic acid and 2mercaptoethanol to the extraction medium. Relative mobility of the isozyme bands was calculated with referrence to a bromophenol blue dye front (table 2). The proportion of polymorphic loci $(P)$, the mean number of alleles per polymorphic locus $(A)$, and the mean heterozygosity per individual $(H)$ were estimated for the parental generation only (table 1). Esterase data has been omitted from these estimates because of uncertainty concerning the genetic basis of the high level of variability found.

\section{RESULTS AND DISCUSSION}

Table 2 is a diagramatic representation of the observed phenotypes of the parental and $F_{1}$ generations, together with $R_{f}$ values of the bands. Fig. I shows some of the gels upon which the diagram is based. Where more than one isozyme per enzyme occurs, the groups of bands are numbered according to increasing distance from the anode. There were areas of enzyme activity associated with several of the enzyme systems which were not well defined under the electrophoretic conditions applied. Only bands which resolved clearly and unambiguously have been considered in the following analysis.

No variation was observed in the single bands of $M E, 6 P G D H-1, G D H, C A T, S O D-2$ and $S O D$. 3 . It is therefore assumed that these isozymes are 


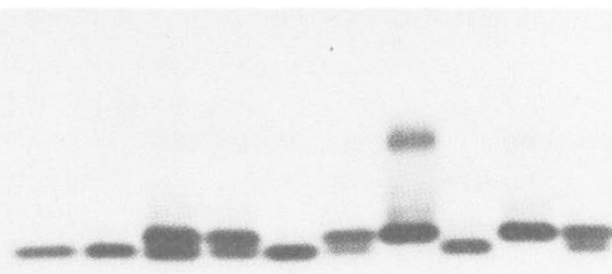

(a) $\mathrm{ACPH}$

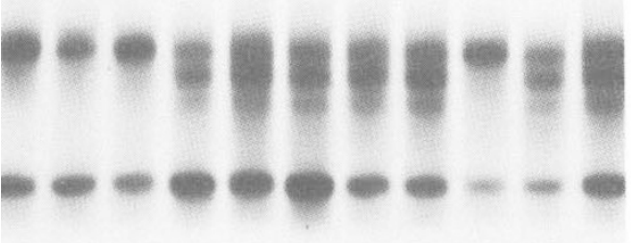

(c) 6-PGDH

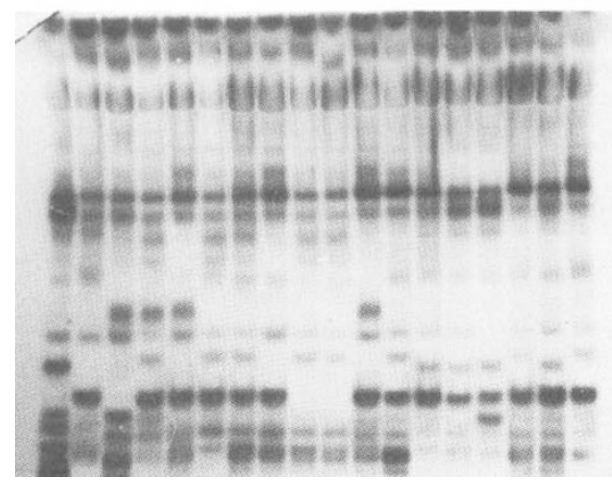

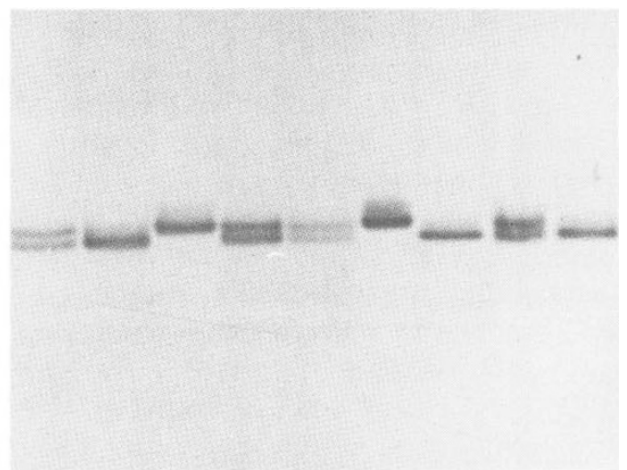

(b) PER

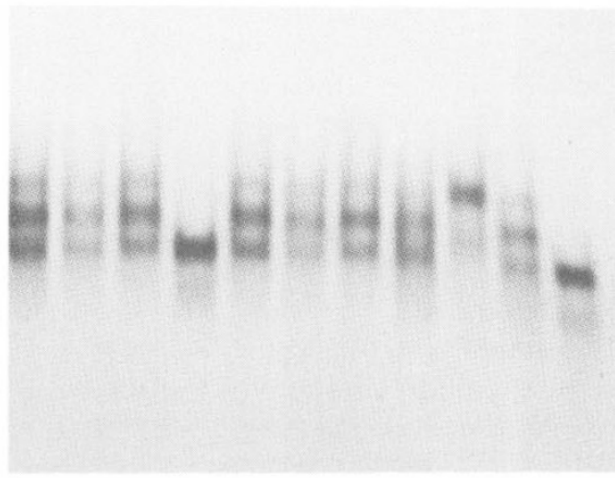

(d) $\mathrm{MDH}$

Figure 1 Electrophoretic phenotypes of six enzyme systems showing allozyme segregation in the $F$ generation (see table 2)

each controlled by a single monomorphic locus in this population. The non-segregating multiplebanded invariant patterns of IDH, GOT-2 and GOT-3 are also considered to result from monomorphic loci and may be due to gene duplication followed by mutation, to post-translational modification leading to secondary isozymes, or to aggregation or proteolysis during extraction and electrophoresis (Harris, 1969). These patterns have been found in all Taraxacum individuals assayed for GOT and $I D H$ to date, including both polyploids and diploids. The GOT zymograms sometimes included a band intermediate to the two invariant groups of three bands (fig. 1f). This band 
did not appear consistently within individuals, did not segregate in the progeny, and is evidently not genetic in origin. No variation within individuals was found for any other enzyme system. No information relating to sub-unit structure of the enzymes can be inferred from monomorphic loci.

The genetic interpretation of the remaining variable loci is based upon the segregation of progeny phenotypes, which was consistent with Mendelian inheritance of co-dominant alleles. $T Y R$, $P E R, S O D-1, G O T-1$ and ACPH each have two alleles with single banded homozygotes and double banded heterozygotes suggesting that the isozymes are monomers. $M D H$ and $6 P G D H-2$ have single banded homozygotes and triple banded heterozygotes indicating that these isozymes are dimers. $M D H$ has two alleles; a single individual had a unique triple banded $6 P G F H-2$ phenotype which may have been due to a third allele for this isozyme, in addition to two common alleles. This individual was not used as a parent for the $F_{1}$ generation.

A straightforward genetic interpretation cannot be applied to the complex esterase zymograms, as the banding patterns in the offspring were not always compatible with those of the parents. In spite of consistent and clear resolution of bands for individual plants, progeny zymograms may show bands that are absent in the parents, or lack bands that are clearly present in the parents. Only one band has appeared in all individuals; this is designated EST-4 and is presumed to be controlled by a monomorphic locus. Three groups of bands can be explained by assuming a high proportion of null alleles. EST-1 and EST-3 have a single active allele and a null allele; EST-2 has a null allele and two closely migrating active alleles which appear in the heterozygote as a single thick band. Parental individuals heterozygous for the null allele were inferred from the phenotype of the progeny. The heterozygosity values for EST in table 1 are based on individuals used in crosses only, as null-heterozygotes cannot be identified in the rest of the sample. The $\chi^{2}$ values for observed and expected progeny phenotypes of crosses involving these loci are consistent with such an interpretation, but depend upon high frequencies for the null allele at each locus. Minimum frequencies, calculated for the sample from homozygous null individuals only, are $0 \cdot 18,0.21$ and 0.11 for $E S T-1, E S T-2$ and $E S T-3$ respectively. Null alleles do not generally occur at high frequencies in natural populations (Rick and Fobes, 1975). Even if this interpretation of part of the EST zymograms is correct, the three EST loci with null alleles are of little value as genetic markers in studies of variation, as heterozygotes cannot be readily identified. The difficulty we found in resolving the heritability of the EST isozymes shows that it is important for enzyme systems to be subjected to genetic analysis when used in evolutionary studies. It indicates that simple "band counting" is an inadequate method of estimating variation.

The present isozyme survey of 12 enzyme systems has resulted in the identification of 16 loci, 44 per cent of which are polymorphic, with four tentative EST loci in addition. The small sample size, and the limitations of electrophoresis as a means of detecting total genetic variation, particularly in this instance where unresolved enzyme activity has been ignored, do not allow an accurate estimation of the total genetic variation in the parental population. It is clear from table 1, however, that the amount of variation within the sample is considerable. The heterozygosity level, calculated over both polymorphic and monomorphic loci, is $0 \cdot 19$. This exceeds the mean for allozyme variation in predominantly outcrossing plants given by Selander (1976) of $0 \cdot 17$. Gottlieb (1981) quotes heterozygosities in outcrossing plants, including both obligate and facultative outbreeders, ranging from 0 to 0.37 with a mean of 0.086 . The dandelions in this sample derive from hybridisation between two self-incompatible species which have no observable breeding barriers between them. The high level of heterozygosity might be expected in plants originating from a hybrid swarm of randomly crossing obligate outbreeders.

Larger samples from other French hybrid populations have since been established, and should confirm whether or not such high levels of heterozygosity are generally to be found in diploid Taraxacum populations. Preliminary isozyme surveys of agamosperms from the same section of the genus Taraxacum as the sexual plants analysed here, indicate very similar banding patterns. This confirms a close evolutionary relationship. Valid extrapolation of the genetic basis of isozyme loci from the sexual diploids to the apomictic triploids should therefore be possible. This would allow a comparison of the genetic variation associated with both groups to be made.

Acknowledgements Mrs Hughes is supported by a NERC research studentship, 6T4/TLS/82/37. 


\section{REFERENCES}

ASKER, S. 1979. Progress in apomixis research. Hereditas, 91, $231-240$.

BROWN, A. H. I). 1979. Enzyme polymorphism in plant populations. Theor. Pop. Biol., 15, 1-42

FÜRNKRANZ, D. 1960. Cytogenetische Untersuchungen an Taraxacum im Raume von Wien. Österr. Bot. Z., 107,311349.

FÜRNKRANZ, D. 1961. Cytogenetische Untersuchungen an Taraxacum im Raume von Wien. II Hybriden zwischen $T$. officinale and T. palustre. Österr. Bot. Z., 108, 408-415.

FÜRNKRANZ, D. 1966. Untersuchungen an Populationen des Taraxacum officinale-Komplexes im Kontaktgebiet der diploiden und polyploiden Biotopen. Österr. Bot. Z., 113, 427-447.

GOTTLIEI3, L. D. 1981. Electrophoretic evidence and plant populations. Prog. Phytochem., 7, 1-46.

HAMRICK, J. L., LINHART, Y. B. ANI MITTON, J. B. 1979. Relationships between life history characteristics and electrophoretically detectable genetic variation in plants. Ann. Rev. Ecol. Syst., 10, 173-200.

HARRIS, H. 1969. The principles of human biochemical genetics. Frontiers of Biology. North Holland Publishing Co. Amsterdam.

JENNISK FNS, M. J. 1984. Karyogeography of Taraxacum sect, Taraxacum (= sect. Vulgaria) and the possible occurrence of facultative agamospermy in Bavaria (GFR) and northwestern Austria. Phyton, (Austria) 24, 11-34.

LEWONTIN, R. C. 1974. The Genetic Basis of Evolutionary Change. Columbia University Press, New York.

Mogle, M. 1982. The status of Taraxacum agamospecies. Ph.D. Thesis, University of Newcastle upon Tyne.
MOGIE, M. AND RICHARIDS, A. J. 1983. Satellited chromosomes, systematics and phylogeny in Taraxacum (Asteraceae). Pl. Syst. Evol, 141, 219-229.

MÜLLER, U. 1972. Zytologisch-embryologische Beobachtungen an Taraxacum-Arten aus der Sektion Vulgaria Dahlst. in der Schweiz. Ber. Geobot Inst. ETH Stifiung Rubel, 4l, 48-55.

NIJS, J. C. M. DEN AND STERK, A. A. 1980. Cytogeographical studies of Taraxacum sect. Taraxacum (= sect. Vulgaria) in central Europe. Bot. Jahrb. Syst., 101, 527-554.

NIJS, J. C. M. DE,N AND STERK, A. A. 1984a Cytogeography of Taraxacum sect. Taraxacum and sect. Alpestria in France and some adjacent parts of Italy and Switzerland, including some taxonomic remarks. Acta Bot. Neerl., 33, 1-24.

NIJS, J. ( . M. DEN AND STERK, A. A. 1984 b. Cytogeography and cytotaxonomy of some Taraxacum sections in Belgium and northern France. Acta Bot. Neerl. 27, 287-305.

RICHARISS, A. J. 1970. Eutriploid facultative agamospermy in Taraxacum. New Phytol., 69, 761-774.

RICK, C. M. AND FOBE.S, J. F.1975. Allozymes of Galapagos tomatoes: polymorphism, geographic distribution, and affinities. Evolution, 29, 443-457.

SCANDALIOS, J. G. 1969. Genetic control of multiple molecular forms of enzymes in plants: a review, Biochem. Genet., 3, 37-79.

SELANDER, K. K. 1976. Genic variation in natural populations. In Ayala, F. J. (ed.) Molecular Evolution. Sinauer Associates Inc. Sunderland, Mass., pp. 21-45.

STERK, A. A., NIJS, J. C. M. DEN ANI) KREUNE, w. 1982. Sexual and agamospermous Taraxacum species in the Netherlands. Acta Bot. Neerl., 31, 227-237. 